\title{
Dual-purpose production of eggs and meat - Part 1: cockerels of crosses between layer and meat breeds achieve moderate growth rates while showing unimpaired animal welfare
}

\author{
Lisa Baldinger (D) Ralf Bussemas
}

Received: 10 September 2020 / Accepted: 4 May 2021 / Published online: 29 May 2021

(C) The Author(s) 2021

\begin{abstract}
The use of modern chicken genotypes with high egg or meat performance results in the ethically unacceptable practice of culling day-old male layer chicks because of their inefficient fattening performance. Dual-purpose genotypes with a balanced performance profile for both eggs and meat are one option to avoid this practice. In this study, four chicken crosses of a layer breed (White Rock or New Hampshire) and the meat breed Bresse Gauloise were compared under the conditions of organic agriculture. Purebred Bresse Gauloise and the layer hybrid Lohmann Sandy served as controls. Part 1 of this study focused on the fattening performance of the cockerels, which were reared together with the pullets. The birds were housed in a floor system (9.9-20.7 kg live weight per $\mathrm{m}^{2}$ at the end of week 15) with access to a green outdoor run. Live weight of the crosses before slaughter at the age of 15 weeks ranged between 2355 and $2447 \mathrm{~g}$ and did not differ significantly between the genotypes. With average daily gains of 22.1$22.8 \mathrm{~g}$, the crosses grew slower than Bresse Gauloise males $(26.1 \mathrm{~g})$ but faster than Lohmann Sandy males $(15.9 \mathrm{~g})$. Welfare assessment indicated a generally high level of welfare with no foot pad lesions or hock burns on any of the cockerels. Fattening dual-purpose cockerels can therefore be an ethically desirable
\end{abstract}

L. Baldinger $(\bowtie) \cdot$ R. Bussemas

Thünen Institute of Organic Farming, Trenthorst 32,

23847 Westerau, Germany

e-mail: lisa.baldinger@thuenen.de option with a high level of animal welfare and a better fattening performance than in male layer chicks, but still requires more resources than the fattening of specialised broilers.

Keywords Broiler $\cdot$ Brother rooster $\cdot$ Dual-purpose chicken

\section{Introduction}

Breeding chickens for eggs and meat is a comparatively recent practice and only gained momentum in the nineteenth century, with most birds then being dual-purpose breeds (Wood-Gush 1959). The discovery of the Mendelian principles, the application of crossbreeding, and the development of sexing methods for day-old chicks resulted in the specialised, highly efficient layers and broilers we know today (Leenstra and Sambeek 2014). Because of the negative genetic correlation between growth and reproductive performance, the downside of highperformance layers is the poor fattening performance of their males. The resulting practice of culling dayold male layer chicks, however, has recently raised strong moral concerns in Germany and other European countries (Reithmayer et al. 2019), despite the fact that most of the chicks are fed to zoo animals and pets. The search for alternatives is still in progress, with in ovo sexing, the fattening of brother roosters, and the use of dual-purpose chickens as the main 
options (Krautwald-Junghanns et al. 2018). Dual-purpose chickens are characterised by their ability to produce both eggs and meat, albeit with lower efficiency than specialised layers and broilers. Both pure breeds, crosses between layer and meat breeds, as well as commercial dual-purpose chickens, are available.

A popular pure breed used on small-scale poultry farms with direct marketing in Germany is the Bresse Gauloise, which originates from the Bresse region in France and combines high meat quality with a laying performance of up to 250 eggs (de Craigher 2015). Muth et al. (2018) found that the growth performance of Bresse Gauloise males ( $31 \mathrm{~g}$ daily gain until week 12) lies between the performance of females and males of the slow-growing broiler ISA 657 (26 and $34 \mathrm{~g}$ daily gain until week 12) when fattened under organic conditions in Germany. Under tropical free-range conditions in Tenerife (Spain), Torres et al. (2019) found that Bresse Gauloise males (35 g maximum daily gain) performed better than a Spanish local breed (Canarian, $27 \mathrm{~g}$ maximum daily gain) and the commercial dual-purpose genotype Dominant Red Barred (30 g maximum daily gain). An example of a cross between a meat breed and a layer breed is the Bresse $\mathrm{x}$ White Rock cross-tested by Nolte et al. (2020) in comparison to purebred Bresse Gauloise and others. The White Rock is a layer breed; consequently, Nolte et al. (2020) found that the performance of the cross (1536 $\mathrm{g}$ body weight at 10 weeks) was inferior to the purebred Bresse Gauloise males (1823 g body weight at 10 weeks). An example of a commercial dual-purpose chicken is Lohmann Dual, for which the breeding company Lohmann Tierzucht used a sex-linked dwarf gene to produce small hens and normal-sized cockerels (Icken and Schmutz 2013). In a Swiss study conducted by Mueller et al. (2018) in a conventional system, Lohmann Dual males (34 g daily gain until week 9) could compete with the slow-growing broiler Sasso 51 (38 g daily gain until week 9), but both grew much slower than the fast-growing broiler Ross PA3 (68 g daily gain until week 5).

Based on these reports, we see the need for further work on the growth performance and husbandry of currently available dual-purpose chickens in order to supply information for interested farmers as well as the breeding organisations. In Germany, crosses of the meat breed Bresse Gauloise and the layer breeds White Rock and New Hamsphire are produced by
Ökologische Tierzucht gGmbH (ÖTZ), a breeding organisation founded by the organic farming associations Bioland and Demeter. The focus of our study was to compare crosses of Bresse Gauloise $\mathrm{x}$ White Rock and Bresse Gauloise x New Hampshire from ÖTZ stock, as well as their reciprocal versions, under organic housing and feeding conditions. Purebred Bresse Gauloise and the layer hybrid Lohmann Sandy were used as controls. To our knowledge, this is the first study to compare the reciprocal versions of the crosses and the first to report performance data under the conditions of organic agriculture. The research questions included the fattening performance of the males under mixed-sex rearing, the laying performance of the females, differences in animal welfare indicators, and differences caused by the position of the parents (e.g. Bresse Gauloise mother vs Bresse Gauloise father). The fattening performance of the males is covered in this article; for the laying performance of the females, see the companion paper "Dual-purpose production of eggs and meat - Part 2: hens of crosses between layer and meat breeds show moderate laying performance but choose feed with less methionine than a layer hybrid, indicating the potential to reduce feed cost" in this issue.

\section{Animals, materials, and methods}

Animals and experimental design

The study was conducted between March 2017 and August 2018. Each dual-purpose genotype was the cross of a layer breed (White Rock or New Hampshire) and the meat breed Bresse Gauloise, resulting in the following crosses ( $\lesssim \mathrm{x}$ ㅇ): Bresse Gauloise $\mathrm{x}$ White Rock (Bresse x WR), White Rock x Bresse Gauloise (WR x Bresse), Bresse Gauloise x New Hampshire (Bresse $x \mathrm{NH}$ ), and New Hampshire $\mathrm{x}$ Bresse Gauloise (NH x Bresse). All purebred parent birds were in possession of Ökologische Tierzucht gGmbH (ÖTZ, Mainz, Rheinland-Palatinate), and the parent flocks for producing the crossbred chicks were assembled specifically for this study by ÖTZ. White Rock and Bresse Gauloise parents for producing the White Rock crosses were kept on an organic laying hen farm in Goch-Hommersum, North Rhine-Westphalia, while New Hampshire and Bresse Gauloise parents for producing the New Hampshire crosses 
were kept on an organic laying hen farm in Freising, Bavaria. In addition to the crosses, a meat breed and a layer hybrid were included as controls: hatching eggs of purebred Bresse Gauloise (Bresse) came directly from ÖTZ stock (Ueberlingen, Baden-Wuerttemberg), and those of the layer hybrid Lohmann Sandy (Sandy) were purchased from Eiermacher $\mathrm{GmbH}$ in Kremsmünster, Austria.

All chicks except the New Hampshire crosses hatched at the same hatchery in Eppingen, BadenWuerttemberg. Because of transport limitations due to an outbreak of the avian flu in winter 2016/2017, the New Hampshire crosses hatched in a different hatchery in Blumegg, Baden-Wuerttemberg. All eggs were placed in incubators on February 20, 2017, and the chicks hatched on March 15. Animal husbandry of both the parent flocks and the crosses followed the rules of the European Council Regulation EC 834/2007 (European Union 2007a) and the production guidelines of the organic farming association Demeter (Demeter 2015).

The mixed-sex rearing period took place on an organic farm (Bauckhof Klein Süstedt, Uelzen, Lower Saxony) and lasted from March 15 until June 28, 2017 (15 weeks). Of each genotype, one group of 157-310 chicks of mixed-sex was reared (Bresse $\mathrm{x}$ WR: 190; WR x Bresse: 310; Bresse x NH: 157; NH $x$ Bresse: 233; Bresse: 293; Sandy 238). There were no replicates in the sense of several groups of birds per genotype, but for all data measured on individual birds (live weight, welfare indicators), the chicken within the group represent the replicates of the genotype. All chicks were vaccinated against Marek's disease, Newcastle disease, Salmonella, Mycoplasma, infectious laryngotracheitis, infectious bronchitis, infectious bursitis, coccidiosis, and rhinotracheitis, while the vaccinations against Escherichia coli and egg drop syndrome were only given to the pullets in week 15 .

\section{Housing and feeding}

The chicks were housed under floor husbandry conditions in a mobile barn of $126 \mathrm{~m}^{2}$ (type Rundbogen, Wördekemper GmbH \& Co. KG, Rietberg, North Rhine-Westphalia) divided into six compartments of $17.5 \mathrm{~m}^{2}$ indoor and $12.5 \mathrm{~m}^{2}$ roofed outdoor area each. The pens were separated by wire mesh, and the outdoor runs were separated by fences to avoid mixing of the genotypes. Access to the roofed outdoor area and the adjacent green outdoor area was first granted when the chicks were 6 weeks old. Thereafter, the chickens had access to the roofed outdoor area every day, but access to the green outdoor run was only granted when it did not rain (in total 5 five days without access). The compartments were bedded with wood shavings and equipped with drinkers, troughs, and wooden perches. The feeding regimen was the same for all genotypes and was divided into three periods (see Table 1 for nutrient composition). The feed mixtures were purchased at a commercial feed mill (Meyerhof zu Bakum GmbH, Melle, Lower Saxony) and were of $100 \%$ organic origin. Changes from one period to the next were done gradually over a period of 3 days.

Data collection

At the age of 6 weeks, all birds were marked with foot rings to enable individual documentation of live weight and animal welfare indicators. Data collection included feed consumption, individual live weight and animal welfare indicators, slaughter performance, and animal losses. Feed consumption was documented per genotype (mixed sex) by collecting feed refusals every 3 weeks. All cockerels were weighed at the age of 6 weeks. At the age of 11 and

Table 1 Analysed nutrient composition of the feed mixtures, g $\mathrm{kg}^{-1}$ (as fed) unless stated otherwise

\begin{tabular}{llll}
\hline Nutrients & $\begin{array}{l}\text { Starter feed } \\
\text { week 1-3 }\end{array}$ & $\begin{array}{l}\text { Grower 1 } \\
\text { week 4-6 }\end{array}$ & $\begin{array}{l}\text { Grower } \\
\text { 2 week } \\
7-15\end{array}$ \\
\hline Crude protein & 238 & 213 & 169 \\
Ether extracts & 85 & 69 & 50 \\
Crude fibre & 89 & 61 & 74 \\
Starch & 266 & 316 & 384 \\
Sugar & 49 & 40 & 38 \\
MJ AME & 11.7 & 11.5 & 11.3 \\
Lysine & 11.7 & 9.8 & 7.2 \\
Methionine & 4.2 & 3.7 & 2.9 \\
Cysteine & 4.0 & 3.6 & 3.1 \\
g methionine & 0.36 & 0.32 & 0.26 \\
$\quad$ MJ $^{-1}$ AME & & & \\
Calcium & 11.1 & 14.6 & 7.5 \\
Phosphorus & 9.8 & 12.1 & 8.0 \\
\hline
\end{tabular}


13 weeks, 20 cockerels of each genotype were randomly selected from all areas of the respective pens and slaughtered, and all remaining cockerels followed at the age of 15 weeks (Bresse x WR: 32; WR x Bresse: 32; Bresse x NH: 22; NH x Bresse: 27; Bresse: 56; Sandy 106). On the days before slaughter, the cockerels were weighed and scored for selected animal welfare indicators based on a simplified version of the Welfare Quality ${ }^{\circledR}$ Protocol (2009) where score " 0 " indicates an unimpaired state; score " 1 " indicates minor lesions, dirtiness etc.; and score "2" indicates major lesions, dirtiness etc. The animal welfare indicators included pecking wounds on the comb, breast blisters, cleanliness of back feathers, foot pad lesions, and hock burns. Slaughter performance of the cockerels could only be measured on a group basis on the slaughtering dates in weeks 13 and 15. For each genotype, the sum of the carcasses and the sum of the valuable cuts (whole legs, breast fillet) were weighed.

From every feed mixture fed, one bulk sample was collected and sent to a commercial laboratory for nutrient analysis. The analysis was done according to the European Commission Regulation EC 152/2009 (European Union 2009), and method numbers are given below. The dry matter content of feed was determined by oven-drying at $103{ }^{\circ} \mathrm{C}$ (Annex III, A). Ash, ether extracts, sugar, and starch contents were analysed using methods M, H, J, and L of Annex III. Contents of crude protein were calculated from nitrogen content, which was determined according to the Kjeldahl method (Annex III, C). Contents of nitrogen corrected metabolisable energy $\left(\mathrm{AME}_{\mathrm{N}}\right)$ were calculated according to EC 152/2009 Annex VII. Amino acid concentrations were determined with a chromatographic system according to Annex III, F, using samples that had been hydrolysed in $6 \mathrm{M} \mathrm{HCl}$ for $20 \mathrm{~h}$. For analysis of methionine and cysteine concentration, samples were oxidised before hydrolysis to avoid losses.

\section{Statistical analysis}

The experimental design did not include replicates in the sense of several groups of birds per genotype; therefore, the differences in measures taken on individual birds (live weight, daily weight gain, animal welfare indicators) refer to birds kept together in one group per genotype. All statistical analyses were conducted using SAS 9.4. proc glimmix, and P values $<0.05$ were interpreted as indicating significant differences.

For the analysis of live weight and daily weight gain, the model included the fixed effects of genotype, week of life $(6,11,13,15)$, and their interaction. Only data from birds that were weighed at least twice remained in the dataset. Slaughter performance of cockerels is given as raw data. Multiple comparisons of means were made using the Tukey's test.

For the analysis of animal welfare indicators, the frequency of scores 0,1 , and 2 was compared for each sampling date using proc glimmix (chi ${ }^{2}$ test, multinomial distribution). The model included only the fixed effect of genotype, and $\mathrm{P}$ values in multiple comparisons of means were adjusted according to Bonferroni-Holm.

\section{Results}

Feed consumption

Feed consumption during the rearing period was documented per genotype and therefore refers to mixedsex groups. Unfortunately, WR x Bresse chicks repeatedly slipped through holes in the netting into the neighbouring pen of Bresse $\mathrm{x} \mathrm{NH}$, which resulted in differences in feed consumption that are not related to genotype but to differing animal numbers. Therefore, no statistical analysis of feed consumption was conducted. Calculated as arithmetic means, and not corrected for the above mentioned problem, average feed consumption per bird and day until the last cockerels were slaughtered (week 15) was $81 \mathrm{~g}$ for Bresse $\mathrm{x}$ WR, $68 \mathrm{~g}$ for WR $\mathrm{x}$ Bresse, $84 \mathrm{~g}$ for Bresse $\mathrm{x} \mathrm{NH}$, $80 \mathrm{~g}$ for $\mathrm{NH} \times$ Bresse, $77 \mathrm{~g}$ for Bresse, and $75 \mathrm{~g}$ for Sandy.

Fattening and slaughter performance

Due to marketing reasons on the farm where the rearing period took place, Bresse cockerels were not weighed and slaughtered at the age of 11 weeks, and Sandy cockerels were not weighed and slaughtered at the age of 13 weeks. At the ages when they were weighed, Bresse cockerels had the significantly highest and Sandy cockerels the significantly lowest body weight and daily weight gain (see Table 2). Body weights and daily weight gain of the crosses 
Table 2 Least square means of live weight and daily weight gain of dual-purpose cockerels. WR White Rock, $N H$ New Hampshire, Bresse Bresse Gauloise, Sandy Lohmann Sandy

\begin{tabular}{|c|c|c|c|c|c|c|c|c|}
\hline & \multicolumn{8}{|l|}{ Genotype } \\
\hline & Bresse $\mathrm{x}$ WR & WR x Bresse & Bresse $\mathrm{x}$ NH & NH x Bresse & Bresse & Sandy & SEM $^{\mathrm{x}}$ & $\mathrm{P}$ value ${ }^{\mathrm{y}}$ \\
\hline \multicolumn{9}{|l|}{ Live weight, $\mathrm{g}$} \\
\hline 6 weeks & $659^{\mathrm{b}}$ & $675^{\mathrm{b}}$ & $685^{\mathrm{b}}$ & $688^{\mathrm{b}}$ & $854^{\mathrm{c}}$ & $430^{\mathrm{a}}$ & $15.1-19.3$ & $<0.001^{\mathrm{z}}$ \\
\hline 11 weeks & $1537^{\mathrm{b}}$ & $1512^{\mathrm{b}}$ & $1621^{b}$ & $1601^{b}$ & & $1118^{\mathrm{a}}$ & $32.2-33.1$ & \\
\hline 13 weeks & $2004^{\mathrm{ab}}$ & $1910^{\mathrm{a}}$ & $2097^{b}$ & $2051^{b}$ & $2446^{c}$ & & $23.0-28.0$ & \\
\hline 15 weeks & $2393^{b}$ & $2355^{\mathrm{b}}$ & $2447^{b}$ & $2402^{\mathrm{b}}$ & $2780^{c}$ & $1705^{\mathrm{a}}$ & $31.5-37.1$ & \\
\hline \multicolumn{9}{|c|}{ Daily weight gain until slaughter, g } \\
\hline 11 weeks & $19.5^{\mathrm{b}}$ & $19.2^{\mathrm{b}}$ & $20.6^{\mathrm{b}}$ & $20.3^{\mathrm{b}}$ & & $14.1^{\mathrm{a}}$ & $0.45-0.47$ & $<0.001$ \\
\hline 13 weeks & $21.6^{\mathrm{ab}}$ & $20.6^{\mathrm{a}}$ & $22.6^{\mathrm{b}}$ & $22.1^{\mathrm{ab}}$ & $26.5^{\mathrm{c}}$ & & $0.33-0.40$ & \\
\hline 15 weeks & $22.4^{\mathrm{b}}$ & $22.1^{\mathrm{b}}$ & $22.8^{\mathrm{b}}$ & $22.4^{\mathrm{b}}$ & $26.1^{\mathrm{c}}$ & $15.9^{\mathrm{a}}$ & $0.45-0.53$ & \\
\hline
\end{tabular}

${ }^{\mathrm{x}}$ Standard errors of the means, given as range; ${ }^{\mathrm{y}} \mathrm{P}$ value of the effect of genotype; ${ }^{\mathrm{z}} \mathrm{P}$ value genotype* week;

Least square means with no letter in common indicate significant differences

were always in the range between those of Bresse and Sandy. There were no significant differences between the crosses, except for week 13 when the WR*Bresse cockerels had a significantly lower body weight than the New Hampshire crosses and a significantly lower daily weight gain than the Bresse* $\mathrm{NH}$ cross. Table 3 gives detailed information on the slaughter performance of the cockerels. Whenever Bresse cockerels were slaughtered, their carcass weight was higher than in all other genotypes. Whenever Sandy cockerels were slaughtered, their dressing percentage was lower than in all other genotypes. Within the crosses, dressing percentage and percentage of the valuable cuts increased in most genotypes with increasing slaughter age. The feed conversion ratio was not statistically analysed due to difficulties in the documentation of feed consumption (see above). Calculated as arithmetic means, feed conversion ratio until slaughter at the age of 15 weeks was 3.6 for Bresse $x$ WR, 3.1 for WR x Bresse, 3.7 for Bresse x NH, 3.6 for $\mathrm{NH}$ $\mathrm{x}$ Bresse, 3.0 for Bresse, and 4.7 for Sandy.

Animal welfare

Of all animal welfare indicators, significant differences between the genotypes were only found for
Table 3 Slaughter performance of dualpurpose cockerels. WR White Rock, $N H$ New Hampshire, Bresse Bresse Gauloise, Sandy Lohmann Sandy

$\mathrm{x} \%$ of carcass weight. Breast, breast fillets; Legs, whole legs

\begin{tabular}{|c|c|c|c|c|c|c|}
\hline & \multicolumn{6}{|l|}{ Genotype } \\
\hline & Bresse $x$ WR & WR $x$ Bresse & Bresse $\mathrm{x}$ NH & NH $x$ Bresse & Bresse & Sandy \\
\hline \multicolumn{7}{|c|}{ Age at slaughter 11 weeks } \\
\hline Carcass weight, $\mathrm{g}$ & 890 & 875 & 925 & 900 & & 600 \\
\hline Dressing, $\%$ & 58 & 58 & 57 & 56 & & 53 \\
\hline \multicolumn{7}{|c|}{ Age at slaughter 13 weeks } \\
\hline Carcass weight, $\mathrm{g}$ & 1183 & 1143 & 1177 & 1177 & 1350 & \\
\hline Dressing, $\%$ & 59 & 60 & 56 & 57 & 55 & \\
\hline Breast, $\%^{x}$ & 15 & 15 & 16 & 16 & 17 & \\
\hline Legs, $\%^{x}$ & 38 & 39 & 40 & 39 & 39 & \\
\hline \multicolumn{7}{|c|}{ Age at slaughter 15 weeks } \\
\hline Carcass weight, g & 1515 & 1350 & 1500 & 1489 & 1720 & 672 \\
\hline Dressing, $\%$ & 66 & 58 & 62 & 62 & 62 & 40 \\
\hline Breast, $\%^{x}$ & 17 & 10 & 17 & 16 & & 19 \\
\hline Legs, $\%^{\mathrm{x}}$ & 41 & 42 & 41 & 40 & & 51 \\
\hline
\end{tabular}


soiled plumage on the back and injuries on the combs. While soiling of plumage on the back did not differ between the genotypes in week 11 and 13, there was a significant effect of genotype in week $15(\mathrm{P}=0.008)$. The prevalence of score 1 for soiled plumage on the back in week 15 ranged from 0 (Sandy) to $52 \%$ (Bresse), with $6-20 \%$ of the crossbred cockerels receiving score 1 . The only score 2 was documented for a Bresse cockerel. Despite these considerable differences, pairwise comparisons revealed no significant differences between the genotypes.

The prevalence of injuries on the combs did not differ in week 11 but significantly differed between the genotypes in week $13(\mathrm{P}=0.002)$ and 15 $(\mathrm{P}<0.001$; Fig. 1). In week 13, Bresse $\mathrm{x}$ WR cockerels received significantly more 0 scores than $\mathrm{NH} x$ Bresse and Bresse cockerels, while Bresse $\mathrm{x}$ NH did not differ from the others. In week 15 , Bresse cockerels differed significantly from Sandy cockerels, with the former receiving only scores 1 and 2, while the latter received mostly scores 0 and 1 . Scores of the crossbred cockerels did not differ from each other and Bresse or Sandy.

No foot pad lesions and hock burns were found on any of the cockerels. Breast blisters appeared in weeks 13 and 15, with the prevalence of score 1 not differing between the genotypes and ranging from 0 to $21 \%$. In week 13 , breast blisters of score 1 were documented on $5 \%$ of Bresse $x$ WR, $6 \%$ of Bresse $x$ $\mathrm{NH}, 21 \%$ of Bresse $\mathrm{x} \mathrm{NH}$, and $16 \%$ of Bresse cockerels. In week 15 , breast blisters of score 1 were found

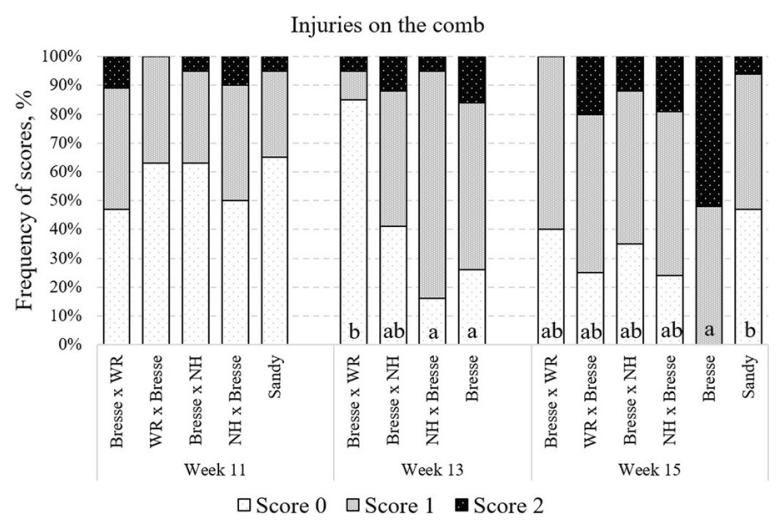

Fig. 1 Injuries on the comb and cleanliness of plumage on the back of dual-purpose cockerels on the day before slaughter, $\%$ of animals with the respective score (score $0=$ unimpaired state; score $1=$ minor changes; score $2=$ major changes; $\mathrm{WR}$, on $7 \%$ of Bresse $x$ WR, $15 \%$ of WR x Bresse, $18 \%$ of Bresse $x \mathrm{NH}$, and $5 \%$ of $\mathrm{NH} \times$ Bresse cockerels. The only score 2 breast blister was documented on an $\mathrm{NH}$ $\mathrm{x}$ Bresse cockerel in week 15 .

Animal losses

Animal losses occurred due to a lack of vitality in the first days of life ( 37 chicks), because of cullings due to congenital leg deformities ( 3 chicks), because some WR x Bresse chicks were crushed to death in a panic (28 chicks), and due to unknown reasons ( 89 chicks). In total, animal losses during mixed-sex rearing amounted to 10.5 and $12.9 \%$ in Bresse $\mathrm{x}$ WR and WR x Bresse, and 9.6 and $6.9 \%$ in Bresse $x$ NH and $\mathrm{NH} \times$ Bresse, respectively. The percentage of animal loss for Bresse and Sandy was 11.9 and 8.8\%, respectively.

\section{Discussion}

This study was conducted in order to compare four chicken crosses between a meat breed (Bresse Gauloise) and a layer breed (White Rock or New Hampshire) with regard to their performance and welfare under the conditions of organic husbandry. The experiment took place on a farm, and one mixed-sex group of 157-310 birds was raised for each genotype.

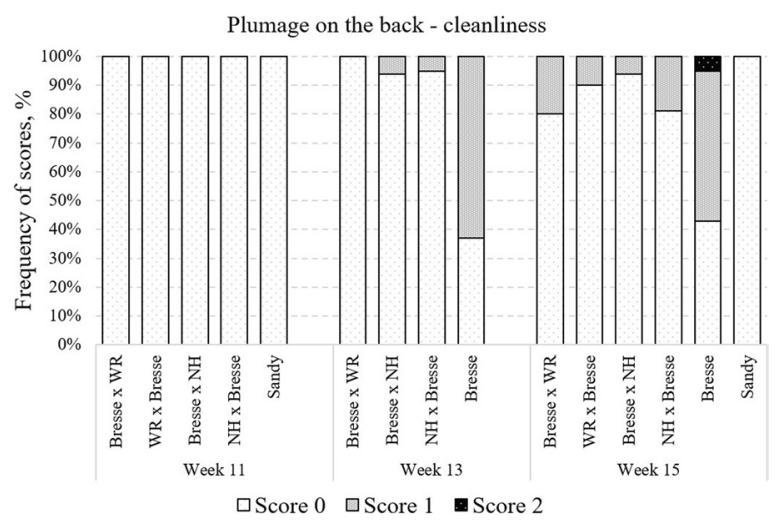

White Rock; NH, New Hampshire; Bresse, Bresse Gauloise; Sandy, Lohmann Sandy; least square means with no letter in common indicate significant differences) 
Fattening and slaughter performance

While Bresse Gauloise can be used as a dual-purpose breed, more focus in its breeding has been put on the meat. Therefore, crossing Bresse Gauloise with layer breeds led to lower daily weight gains of the crosses compared to the pure breeds but still to much faster growth than in cockerels of the layer hybrid Sandy. The fattening performance of Bresse was comparable to reports of Trei et al. (2019; $2655 \mathrm{~g}$ live weight in week 14) for organic feeding. However, the Bresse cockerels in our study grew faster than observed by Torres et al. (2019) under tropical free-range conditions ( $2440 \mathrm{~g}$ live weight in week 15), which is most likely related to differences in climate and husbandry. In a recent feeding trial, Nolte et al. (2020) found a live weight of $1536 \mathrm{~g}$ in 10-week-old Bresse x WR cockerels fed a conventional diet based on soybean and cereals. Although energy and methionine concentration was lower in our study than in Nolte et al. (2020), methionine concentration per MJ was comparable, and our Bresse $\mathrm{x}$ WR cockerels took only 1 week longer to reach the same weight as those raised in the study by Nolte et al. (2020; $1537 \mathrm{~g}$ in week 11). For Bresse $\mathrm{x} \mathrm{NH}$ reared under free-range conditions, Lambertz et al. (2018) reported a live weight of $1865 \mathrm{~g}$ after 12 weeks, of which the first six were mixed-sex rearing. Despite higher energy and amino acid concentrations in the conventional diets fed by Lambertz et al. (2018), the growth rate of their Bresse $\mathrm{x} \mathrm{NH}$ cockerels was comparable to ours, which reached $1621 \mathrm{~g}$ after 11 weeks and $2097 \mathrm{~g}$ after 13 weeks. To our knowledge, our study is the first one to report the fattening performance of WR $x$ Bresse and $\mathrm{NH}$ $x$ Bresse. However, there are reports about their parent breeds: Trei et al. (2019) conducted a study with purebred White Rock, New Hampshire, and Bresse Gauloise birds from ÖTZ stock. They found daily weight gains of $17.8 \mathrm{~g}$ for White Rock, $20.8 \mathrm{~g}$ for New Hampshire, and $25.1 \mathrm{~g}$ for Bresse Gauloise until the age of 14 weeks. Compared with these growth rates, the daily weight gains observed in our study until the age of 15 weeks (22.1-22.8 g) were higher than those reported for White Rock and New Hampshire and lower than those reported for Bresse Gauloise. It can therefore be stated that the growth rates of the crosses were between those previously reported for their parent breeds.
With the exception of a significant difference between WR x Bresse and Bresse $\mathrm{x}$ NH at the age of 13 weeks, there were no significant differences in live weight and daily weight gain of the crosses. We therefore conclude that there are no effects of the position of the parents on the fattening performance of their male offspring, at least not in mixedsex rearing.

Despite growing faster than Sandy cockerels, the daily weight gain of the dual-purpose crosses was much lower than in males of slow-growing broiler strains like Sasso 51 (37.7 g until week 9, Mueller et al. 2018) or Hubbard JA 757 (43.4 g in 8-10 weeks, Hörning et al. 2010). Males of fast-growing broiler strains like Ross 308 (62.2 g in 6.5-7 weeks in organic husbandry, Hörning et al. 2010) show growth rates that are about three times higher than the dualpurpose cockerels in our study. These differences emphasise that the decision for a dual-purpose production system cannot be based on economical facts alone, but on considerations regarding ethics and sustainability.

Slaughter performance was only documented per group but still showed that carcass weights and dressing percentage increased with age at slaughter. Considering that $80 \%$ of German organic meat chicken are sold as cuts (www.oekolandbau.de 2020), a later slaughter date might be beneficial in order to achieve attractive carcasses. Those crossbred cockerels that were slaughtered at the age of 15 weeks had a breast percentage of 10-17, which is in accordance with reports from Trei et al. (2019), who documented 15.3 and $17.5 \%$ breast in purebred White Rock and New Hampshire cockerels aged 16 weeks. Slow-growing broilers like ISA 657 and Sasso 51, however, achieve considerably higher breast percentages of 21.3-23.1 (Muth et al. 2018) and 20.0 (Mueller et al. 2018), with both values referring to mixed-sex fattening. The smaller breast fillets produced with dual-purpose genotypes therefore represent a disadvantage for their marketing. In contrast to breast percentage, the recorded leg percentages of 40-42\% after slaughter at the age of 15 weeks were higher than values reported by Mueller et al. (2018) for the slowgrowing broiler Sasso 51 (32.7\%) and the dual-purpose genotypes Lohmann Dual (35.8\%), Belgian Malines (35.7\%), and Schweizerhuhn (33.8\%). The question of marketing cuts or whole carcasses of the dual-purpose genotypes tested in our study might therefore depend on the possibilities to market the legs at a premium price. 
Animal welfare

The majority of global poultry meat production originates from fast-growing broilers $(89.8 \%$ of the total 127 million t, FAOSTAT 2020). Among the most serious welfare problems encountered in broiler production are contact dermatitis, skeletal disorders, and sudden death syndrome (Bessei 2006). The main levers to improve the welfare of meat birds are to lower their growth rate and the stocking density and to optimise litter and light management. The regulations for organic agriculture demand the use of slowgrowing genotypes, the restriction of the stocking density, and the inclusion of access to an outdoor run with the aim of ensuring good animal welfare (European Union 2007a). Consequently, Tuyttens et al. (2008) found better scores for hock burns and latencyto-lie for organic broiler chicken compared to their conventional counterparts and concluded that broiler chicken welfare is generally superior in organic husbandry. On a scale of $0-3$, with 0 indicating an unimpaired state, Tuyttens et al. (2008) found average foot pad and hock burn scores of 1.03 and 0.30 on organic farms and 1.58 and 1.64 on conventional farms. In our study, no foot pad lesions and hock burns were found on any of the cockerels, indicating an optimal level of animal welfare in this area. In contrast to the lack of foot pad lesions and hock burns, breast blisters with a score of 1 on our scale of $0-2$ were documented in weeks 13 and 15, with the proportion of affected cockerels ranging from 0 to $21 \%$. Foot pad lesions, hock burns, and breast blisters are usually linked to the same causes, namely reduced locomotor activity, high stocking density, and poor litter quality (Bessei 2006). In a study with slow-growing broiler strains, Nielsen (2004) also found an effect of genotype on the incidence of breast blisters and noted that in some genotypes access to perches may increase the appearance of breast blisters. Since there was no effect of genotype in our study, the most likely explanation for the observed prevalence of breast blisters is the use of perches. In purebred Bresse Gauloise and Bresse $\mathrm{x}$ NH cockerels slaughtered at the age of 12 weeks, Lambertz et al. (2018) found that 11.7 and $18.3 \%$ of the birds had breast blisters, which the authors also attributed to the presence of perches.

Soiled plumage has been reported as another result of high stocking density and poor litter quality (Bessei 2006). Statistical analysis of the welfare indicators was done separately for the dates of observation, but still it is clear from Fig. 1 that soiling of the plumage on the back increased with time. This can be explained by the increasing stocking density as a result of the birds' growth. While stocking density did differ between the genotypes and ranged from 9.9 to $20.7 \mathrm{~kg}$ live weight per $\mathrm{m}^{2}$ at the end of week 15 , it was in line with the European regulation for organic agriculture (maximum $21 \mathrm{~kg}$, European Union 2008) and therefore much lower than the $33 \mathrm{~kg}$ upper limit allowed for conventional broilers in Europe (European Union 2007b). Despite a significant effect of genotype on the prevalence of soiled plumage at the age of 15 weeks, pairwise comparison of means did not reveal any significant differences between the genotypes.

Aggressive behaviour plays an important role in the social life of chickens and serves to establish a hierarchy and compete for resources and mating partners (Queiroz and Cromberg 2006). In cockerels, fighting behaviour increases with puberty. We documented injuries on the combs of the cockerels as an indicator of aggressive behaviour. Although the prevalence of injuries was analysed separately for each date, Fig. 1 shows that the proportion of score 2 injuries increased with age, indicating an increasing frequency of fighting behaviour. The highest scores were found for Bresse cockerels at the age of 15 weeks, which is in accordance with the farm personnel's observation that fighting happened most frequently in Bresse birds.

To summarise our findings, the growth performance of the dual-purpose cockerels was between previously reported weight gains for their parent breeds and was in accordance with those few reports available for the crosses. Data about the performance of WR x Bresse and NH x Bresse are first reported in this study and did not differ from the reciprocal versions of the crosses. We therefore conclude that there is no effect of the position of the parents on the fattening performance of their male offspring, at least not in mixed-sex rearing. Welfare assessment indicated a generally high level of animal welfare, with the exception of breast blisters, which were related to the presence of perches in the pens. It should be noted, however, that the study had its limitations, from the limited number of animals and the lack of replicates to the unfortunate mixing of animals between groups which impaired the calculation 
of sound feed consumption values. Further studies with the tested genotypes are therefore necessary in order to reach a final conclusion on their potential for dual-purpose production of meat. Also, successful implementation of a dual-purpose production system will depend not only on the cockerels' growth performance but also on the laying performance of the hens, and on the ethical value that our society puts on raising both sexes.

Acknowledgements The authors would like to thank the project partners Inga Günther (ÖTZ) and Christine Bremer (Bauckhof Klein-Süstedt) for the nice and successful cooperation.

Author contribution All authors contributed to the study conception and design. Material preparation, data collection, and analysis were performed by Lisa Baldinger. The first draft of the manuscript was written by Lisa Baldinger, and Ralf Bussemas commented on previous versions of the manuscript. All authors read and approved the final manuscript.

Funding Open Access funding enabled and organized by Projekt DEAL. Funding by the Lower Saxony Ministry for Nutrition, Agriculture and Consumer Protection is gratefully acknowledged.

Data availability The datasets generated during the study are available from the corresponding author on reasonable request.

\section{Declarations}

Ethics approval No invasive procedure of any kind was used; therefore, no ethics approval was necessary.

Consent for publication All authors agree with the content of the manuscript and have given their consent to submission.

Conflict of interest The authors declare no competing interests.

Open Access This article is licensed under a Creative Commons Attribution 4.0 International License, which permits use, sharing, adaptation, distribution and reproduction in any medium or format, as long as you give appropriate credit to the original author(s) and the source, provide a link to the Creative Commons licence, and indicate if changes were made. The images or other third party material in this article are included in the article's Creative Commons licence, unless indicated otherwise in a credit line to the material. If material is not included in the article's Creative Commons licence and your intended use is not permitted by statutory regulation or exceeds the permitted use, you will need to obtain permission directly from the copyright holder. To view a copy of this licence, visit http://creativecommons.org/licenses/by/4.0/.

\section{References}

Bessei W (2006) Welfare of broilers: a review. World Poultry Sci J 62:455-466

de Craigher GMG (2015) Ökologische Zwei-Nutzungs-Züchtung von Rassehühnern: Zuchtziele und Zuchtorganisation für Bresse Gauloises. Master Thesis, University of Hohenheim

Demeter e.V. (2015) Richtlinien für die Zertifizierung "Demeter" und "Bioynamisch" - version of October 2015. Seklfpublishing, Darmstadt

FAOSTAT 2020. Livestock Primary (world - production quantity - meat, poultry). http://www.fao.org/faostat/ (accessed July 27, 2020)

Hörning B, Trei G, Ludwig A, Rolle E (2010) Suitability of broilers differing in growth intensity for organic agriculture. http://forschung.oekolandbau.de Accessed July 27, 2020

Icken W, Schmutz M (2013) LOHMANN DUAL-Layer and Broiler at the very same time. Poultry News, Lohmann Tierzucht 2:8-10

Krautwald-Junghanns M, Cramer K, Fischer B, Förster A, Galli R, Kremer F, Mapesa EU, Meissner S, Preisinger R, Preusse G, Schnabel C, Steiner G, Bartels T (2018) Current approaches to avoid the culling of day-old male chicks in the layer industry, with special reference to spectroscopic methods. Poultry Sci 97:749-757

Lambertz C, Wuthijaree K, Gauly M (2018) Performance, behavior, and health of male broilers and laying hens of 2 dual-purpose chicken genotypes. Poultry Sci 97:3564-3576

Leenstra F, Sambeek F (2014) Breeding of Laying Hens. LowInputBreeds technical note. http://www.lowinputbreeds. org/fileadmin/documents_organicresearch/lowinputbr eeds/tn-4-1-leenstra-sambeek-2014-poultry-breeding.pdf Accessed July 27, 2020

Mueller S, Kreuzer M, Siegrist M, Mannale K, Messikommer RE, Gangnat ID (2018) Carcass and meat quality of dualpurpose chickens (Lohmann Dual, Belgian Malines, Schweizerhuhn) in comparison to broiler and layer chicken types. Poultry Sci 97:3325-3336

Muth PC, Ghaziani S, Klaiber I, Zárate AV (2018) Are carcass and meat quality of male dual-purpose chickens competitive compared to slow-growing broilers reared under a welfare-enhanced organic system? Org Agr 8:57-68

Nielsen BL (2004) Breast blisters in groups of slow-growing broilers in relation to strain and the availability and use of perches. Brit Poultry Sci 45:306-315

Nolte T et al (2020) Growth performance of local chicken breeds, a high-performance genotype and their crosses fed with regional faba beans to replace soy. Animals 10:702

Queiroz S, Cromberg V (2006) Aggressive behavior in the genus Gallus sp. Braz J Poultry Sci 8:1-14

Reithmayer C, Mußhoff O, Danne M (2019) Alternatives to culling male chicks-the consumer perspective. Brit Food J 122:753-765

Torres A, Muth PC, Capote J, Rodríguez C, Fresno M, Valle Zárate A (2019) Suitability of dual-purpose cockerels of 3 different genetic origins for fattening under free-range conditions. Poultry Sci 98:6564-6571 
Trei G, Brandt L, Kaiser A, Jaschke JJ, Böttcher F, Hörning B (2019) Leistungsprüfung verschiedener Hühnerherkünfte mit Blick auf mögliche Zweinutzung - a) männliche Tiere. In: Mühlrath D, Albrecht J, Finckh MR, Hamm U, Heß J, Knierim U, Möller D (eds) 15th Wissenschaftstagung Ökologischer Landbau. Kassel, Germany

Tuyttens F et al (2008) Broiler chicken health, welfare and fluctuating asymmetry in organic versus conventional production systems. Livest Sci 113:123-132

Union E (2007a) Council Regulation (EC) No 834/2007 of 28 June 2007 on organic production and labelling of organic products and repealing Regulation (EEC) No 2092/91. Off J Eur Union 189:1-23

Union E (2007b) Council Directive 2007/43/EC of 28 June 2007 laying down minimum rules for the protection of chickens kept for meat production. Off $\mathbf{J}$ Eur Union 182:19-28

Union E (2008) Commission Regulation (EC) No 889/2008 of September 5, 2008 laying down detailed rules for the implementation of Council Regulation (EC) No 834/2007 on organic production and labeling of organic products with regard to organic production, labeling and control. Off J Eur Union 250:1-84

Union E (2009) Commission Regulation (EC) No 152/2009 of 27 January 2009 laying down the methods of sampling and analysis for the official control of feed. Off $\mathbf{J}$ Eur Union 54:1060-1130

Wood-Gush D (1959) A history of the domestic chicken from antiquity to the 19th century. Poultry Sci 38:321-326

Welfare Quality® (2009) Welfare Quality® assessment protocol for poultry (broilers, laying hens). Welfare Quality® Consortium, Lelystad, Netherlands

www.oekolandbau.de (2020) Biogeflügel ist eine kleine, aber wachsende Nische. https://www.oekolandbau.de/handel/ marketing/sortiment/sortimentsgestaltung/biogefluegel/ Accessed July 27, 2020

Publisher's note Springer Nature remains neutral with regard to jurisdictional claims in published maps and institutional affiliations. 